\title{
Bioaccumulation of Heavy Metals in Fish, Squids and Crustaceans from the Red Sea, Jeddah Coast, Saudi Arabia
}

\author{
Alaa M. Younis ${ }^{1}$, Hesham F. Amin'1, Ali Alkaladi', Yahia Y. I. Mosleh1 \\ ${ }^{1}$ Aquatic Environment Department, Faculty of Fish Resources, Suez University, Suez, Egypt \\ ${ }^{2}$ Department of Biological Sciences, Faculty of Science, King Abdulaziz University, Jeddah, Saudi Arabia \\ Email: *Ala den@yahoo.com
}

Received 13 June 2015; accepted 14 September 2015; published 17 September 2015

Copyright $@ 2015$ by authors and Scientific Research Publishing Inc.

This work is licensed under the Creative Commons Attribution International License (CC BY). http://creativecommons.org/licenses/by/4.0/

(c) $\underset{\mathrm{EY}}{\mathrm{E}}$ Open Access

\begin{abstract}
Concentration of Cadmium, Copper, Lead, Zinc and Mercury were determined in the muscles, gills and liver of ten fish species (Epinephelus areolatus, Epinephelus radiates, Anthias squamipinnis, Plectorhinchus chaetodonoides, Snubnose emperor, Dicentrarchus labrax, Acanthopagrus bifasciatus, lutjanus kasmira, lutjanus ehrenbergii and Acanthurus gahhm) as well as three specimens of crustaceans (Metapenaeus dalli, Panulirus penicillatus and Portunus petagicus) and two Specimens of squids (Parateuthis tunicate and Chtenopteryx sicula) collected from Jeddah coastal water during 2014. The obtained results declared that, the average concentrations of heavy metals were as follows: Cd (0.098, 0.20, 0.106), Cu (0.358, 0.327, 1.536), Pb $(0.3,0.257,0.196), \mathrm{Zn}(3.00,7.390$, 4.999) $\mu \mathrm{g} / \mathrm{g}$ wet weight in the muscle, gills and liver, respectively. While, the concentration of $\mathrm{Hg}$ was invariably undetectable in all samples of different organs of the collected fish species. The average concentration of $\mathrm{Cd}, \mathrm{Cu}, \mathrm{Pb}, \mathrm{Zn}$ and $\mathrm{Hg}$ in the soft part of the investigated crustaceans (Metapenaeus dalli, Panulirus penicillatus and Portunus petagicus) and squids (Parateuthis tunicate and Chtenopteryx sicula) were relatively higher compared with the muscle tissues in the examined fish species. The results of bioconcentration factor (BCFs) indicated that among examined metals $\mathrm{Zn}$ was the most readily absorbed by fish and the highest BAFs for examined fish species were determined in gill of Snubnose emperor.
\end{abstract}

\section{Keywords}

Bioaccumulation, Fish, Red Sea, Heavy Metals, Bioconcentration Factor

\footnotetext{
${ }^{*}$ Corresponding author.
}

How to cite this paper: Younis, A.M., Amin, H.F., Alkaladi, A. and Mosleh, Y.Y.I. (2015) Bioaccumulation of Heavy Metals in Fish, Squids and Crustaceans from the Red Sea, Jeddah Coast, Saudi Arabia. Open Journal of Marine Science, 5, 369-378. http://dx.doi.org/10.4236/ojms.2015.54030 


\section{Introduction}

Jeddah was first inhabited about 2500 years ago as a small fishing settlement and has long been a center for traders and sailors. From that time, importance of Jeddah was gradually increased and consequently increment the number of inhabitants and visitors. As already known, fishes are the main aquatic products of Jeddah area, seafood lovers from all walks of life can be found browsing through the colourful variety of tender meat that the Red Sea offers. It was estimated that the total fish and shrimps consumption in the kingdom is about 100,000 tons per annum; approximately 49,000 tons are produced locally. In public media, there is a doubt that fishes were contaminated with organic and inorganic pollutants due to the strategic location of Jeddah as one of the international shipping centers and a large number of toxic chemicals and effluent-producing industries are located in and around Jeddah City. Unfortunately, at present, due to discharging high volume of various types of petrochemical industries wastewater as well as wastewater resulting from washing of ships and tankers, the estuary environment could be severely compromised. Also the rapidly developing industrial and municipal development around Jeddah area have caused serious pollution problems in Jeddah coastal waters. Heavy metal pollutions are particularly hazardous contaminants in food and a significant problem in the environment. Several organizations have pointed out the need for monitoring trace metal levels in the marine environment [1] [2]. It is known that some shrimp and crab may provide useful means of monitoring such heavy metal concentrations and their impact on the marine environment. In recent years, much attention has been focused on the concentration of both essential and toxic metals in ecosystems and their component organisms, as a result of a growing concern about the health benefits and risks of food consumption in order to check for those hazardous to human health because they are not biodegradable and have long biological half-lives [3]-[10].

The bioaccumulation of heavy metals varied between species, ages, sex and organs. In general, the target tissues of heavy metals are metabolic active ones which accumulate high levels of metal in fish such as liver and gills, whereas in muscles where the metabolic activity is relatively low accumulates less level of heavy metals.

The measurement of heavy metal concentrations in bio-indicators has been recognized as highly relevant in ecotoxicological terms because of the reflection of bioavailability in the ecosystem that reasonable measurement for public health standards from animals health point of view [11] [12]. Therefore, the objective of the present study is to determine levels of certain heavy metals in fish, squids and crustaceans from the Red Sea.

\section{Material and Methods}

\subsection{Sampling}

Ten fish species (Epinephelus areolatus, Epinephelus radiates, Anthias squamipinnis, Plectorhinchus chaetodonoides, Snubnose emperor, Dicentrarchus labrax, Acanthopagrus bifasciatus, lutjanus kasmira, lutjanus ehrenbergii and Acanthurus gahhm) as well as three Specimens of Crustaceans (Metapenaeus dalli, Panulirus penicillatus and Portunus petagicus) and two specimens of squids (Parateuthis tunicate and Chtenopteryx sicula) have been collected from Jeddah coastal water.

The gills, liver and muscle tissue were isolated and weighed in separate containers, dissected and washed with distilled water. The collected samples were stored in precleaned plastic bags and stored in a freezer at $-20^{\circ} \mathrm{C}$ until the performance of chemical analysis and analyzed for heavy metals according to UNEP/FAO/IAEA/IOC (1984) [13]. Also, the soft tissues of the mussels were separated from the shells and stored in a freezer until chemical analysis.

\subsection{Heavy Metals Determination}

The exact weights of each sample tissue were digested in microwave oven using $\mathrm{HNO}_{3}$ acid in Teflon PTFE tube. The samples were cooled to room temperature and then were transferred to a $25 \mathrm{ml}$ volumetric flask and diluted to $25 \mathrm{ml}$ with $2 \% \mathrm{HNO}_{3}$ in a volumetric flask, then diluted to level with de-ionised water appropriately in the range of standards which were prepared from stock standard solution of the metals (Merck). Before analysis, the samples were filtered through a $0.45 \mu \mathrm{m}$ nitrocellulose membrane filter.

All digested solutions were analyzed in triplicate by Atomic Absorption Spectrophotometer (Shimadzu Model 6800 with graphite furnace, Hydride unit was used for determination of mercury). The instrument setting and operational conditions were done in accordance with the manufacturers specifications. All determinations were in triplicates and sample blanks were prepared in the laboratory in a similar manner to the field samples. The 
concentrations of heavy metals were expressed as $\mathrm{mg} / \mathrm{L}$ of water and $\mu \mathrm{g} / \mathrm{g}$ dry wt for fish samples.

\subsection{Bioconcentration Factor}

The bioconcentration factor (BCF) was calculated for each metals, as the relation between the metal concentrations in fish organs (FC) and its concentration in the water (WC) according to equation: BCF = FC/WC [14].

\section{Results and Discussion}

In the present study, gills and liver are chosen as target organs for assessing metal accumulation higher than the muscle tissue, which usually exhibits a low accumulation potential of metals. Therefore, muscle is chosen because it is the part consumed.

Heavy metal concentration in the muscles, gills and liver of fish species collected from Jeddah coastal waters were illustrated in Table 1.

The distribution pattern of $\mathrm{Zn}$ in the current study in fish muscles, gills and livers ranged from 1.059 to $10.669 \mu \mathrm{g} \cdot \mathrm{g}^{-1}$, from 1.34 to $13.417 \mu \mathrm{g} \cdot \mathrm{g}^{-1}$ and from 0.155 to $9.069 \mu \mathrm{g} \cdot \mathrm{g}^{-1}$ respectively.

In the present study, $\mathrm{Zn}$ was the highest metal in the muscle, gill and liver of analyzed species followed by $\mathrm{Cu}$ as the dominant two metals compared with other determined metals. On the other hand, Hg was generally the lowest (Table 1). Also concentration of $\mathrm{Hg}$ was invariably undetectable in all samples of different organs of fish collected. This may be arising from that mercury was undetectable of their surrounding habitat.

$\mathrm{Zn}$ toxicity is rare, yet it can be toxic above the limit of $50 \mu \mathrm{g} \cdot \mathrm{g}^{-1}$ wet weight in muscle. It appears to have a protective effect against the toxicities of both cadmium and lead [15] [16]. Hence, the relatively high levels of these metals comparing to other metals studied can be attributed to their essentiality [17]. The levels of $\mathrm{Zn}$ in gills of Anthias squamipinnis, Snubnose emperor, Dicentrarchus labrax and Lutjanus ehrenbergii were also higher than the other species studied (Table 1).

The zinc concentration in the samples compares well to the earlier report on the fish species from the Black Sea coasts (9.5 - $22.9 \mathrm{mg} \cdot \mathrm{kg}^{-1}$ ) [18], 33.77 - 246.15 and 18.96 - $39.59 \mathrm{mg} \cdot \mathrm{kg}^{-1}$ for livers and gills respectively for fish from the Egyptian Mediterranean Sea [19].

$\mathrm{Cu}$ concentration in all examined fish species varied from $0.01 \pm 0.001$ to $10.29 \pm 0.01 \mu \mathrm{g} \cdot \mathrm{g}^{-1} \mathrm{dry}$ weight and Acanthopagrus bifasciatus recorded the highest concentration of $\mathrm{Cu}$ in the livers among all the fish species studied.

$\mathrm{Cu}$ levels in the present study are in good agreement with previous recorded values of fish species where the values ranged from 0.23 to $9.49 \mathrm{mg} \cdot \mathrm{kg}^{-1}$ for fish from Marmara Sea [20] and lower when compared with the results obtained by (Khaled, 2013) [19] for muscles (1.05 - 2.56), livers (4.40 - 65.97) and gills (1.20 - 5.90) $\mathrm{mg} \cdot \mathrm{kg}^{-1}$, respectively, of fish from the Egyptian Mediterranean Sea. Also the results of $\mathrm{Cu}$ in the present study were in agreement with Ashraf (2006) [21]; Ashraf et al. (2006) [22] and Al-Yousuf et al. (2000) [23] who observed similar distribution pattern of copper. The higher accumulation ratios of metals in the liver could be due to the greater tendency of the elements to react with the oxygen carboxylate, the amino group, the nitrogen and/or the sulphur of the mercapto group in the metallothionein protein [24]. Although these findings are generally consistent with our results, except the levels of $\mathrm{Cu}$ in the muscle of Anthias squamipinnis and Plectorhinchus chaetodonoides were remarkably higher than some metabolite organs such as the liver and gills (Table 1).

Comparing our average values of Cu with Food and Agricultural Organization's limits for $\mathrm{Cu}$ is $30 \mu \mathrm{g} \cdot \mathrm{g}^{-1}$ [25]. Our results showed that the levels of $\mathrm{Cu}$ in the current study were less than this guideline.

The concentration of $\mathrm{Cd}$ in all fish species varied from $0.001 \pm 0.0004$ to $1.19 \pm 0.002 \mu \mathrm{g} \cdot \mathrm{g}^{-1}$ dry weights. The highest level of Cd was recorded in the gills of Snubnose emperor compared to other species studied.

Cd contents in gills of Epinephelus areolatus, Epinephelus radiates, Anthias squamipinnis, Snubnose emperor, Dicentrarchus labrax and lutjanus ehrenbergii were remarkably higher than muscle and liver.

A lot of researchers have reported that metals accumulate in high concentrations in the gill, the liver and the intestine, because these organs have relatively higher potential for metal accumulation than muscle [26] [27]. Also Jezierska and Witeska (2006) [28] found that Cd is accumulated primarily in the kidney, but it may reach high concentrations also in the gill, digestive tract and spleen. Cd is rarely found in natural water [29]. It is considered to be toxic if its concentration exceeds $0.01 \mathrm{mg} \cdot \mathrm{L}^{-1}$ both in drinking and irrigation water [30]. However, $\mathrm{Cd}$ with some other heavy metals such as lead and mercury are of no biological function in human system and they are potentially toxic even at trace concentrations [31] [32]. Cd injures kidneys and cause symptoms of 


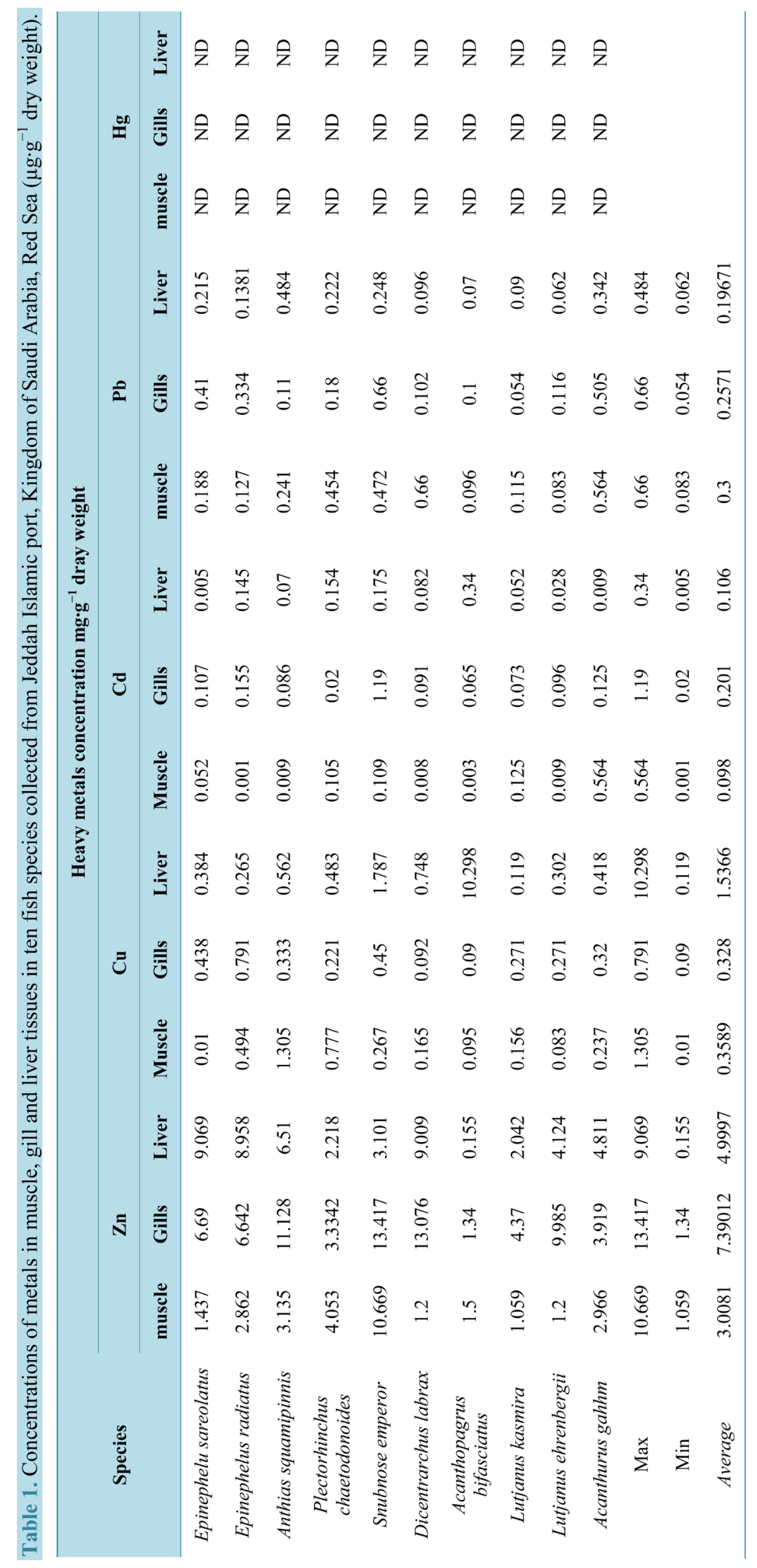


chronic toxicity, including impairment of kidney function, poor reproductive capacity, hypertension, tumors and hepatic dysfunction [33]. Cadmium levels in the present study were generally in similar ranges with the literature, where it has been reported as $0.02-0.24 \mathrm{mg} \cdot \mathrm{kg}^{-1}$ for muscles of fish from the Black Sea coasts [18] and $0.09-0.27,0.30-1.49,0.27-0.66 \mathrm{mg} \cdot \mathrm{kg}^{-1}$ for muscle, liver and gill tissues, respectively, for fish from the Egyptian Mediterranean Sea [19].

Concentrations of $\mathrm{Cd}$ recorded in the current study in the muscle tissues of some fish species were higher than the standard safety level of $\mathrm{Cd}\left(0.04 \mu \mathrm{g} \cdot \mathrm{g}^{-1}\right.$ wet weight) in fish tissue [34] [35]. This could be attributed to the industrial activities situated close to the coast and directly discharges its effluents into it as well as shipping discharge from fishing boats.

The levels of $\mathrm{Pb}$ in all examined fish species fluctuated from $0.054 \pm 0.002$ to $0.66 \pm 0.01 \mu \mathrm{g} \cdot \mathrm{g}^{-1}$ (dry weight). Snubnose emperor and Dicentrarchus labrax recorded the highest concentration of $\mathrm{Pb}$ in the gills and muscle respectively, as well as $\mathrm{Pb}$ content in the muscle of Plectorhinchus chaetodonoides, Dicentrarchus labrax, lutjanus kasmira and Acanthurus gahhm were remarkably higher than some metabolite organs such as the liver and gills (Table 1).

Lead is a neurotoxin that causes behavioral deficits in fish, decreases in survival and growth rates, causes learning disabilities, and metabolism. The World Health Organization has recommended that dietary $\mathrm{Pb}$ should not exceed $0.3 \mu \mathrm{g} \cdot \mathrm{g}^{-1}$ (wet weight) [36].

The results of our investigation shows that, gills of Snubnose emperor seemed to be the organ which accumulates the highest value of $\mathrm{Cd}, \mathrm{Pb}$ and $\mathrm{Zn}$. Target organ, such as gill is metabolically active tissues and accumulate heavy metals of higher levels when compared to other tissues [37]. This is in agreement with Canli et al., (2003) [38]; Al-Yousuf et al. (2000) [23]; Usero et al. (2004) [24] who reported that the differences in metal concentrations of the tissues might be a result of their capacity to induce metal-binding proteins such as metallothioneins.

Furthermore, the adsorption of metals onto the gills surface as the first target for pollutants in water could also be a significant influence in the total metal levels of the gill. This is in agreement with the literature [39]-[42] which reported that heavy metals are stored in the body in various tissues, but the main site of accumulation in aquatic organisms is in the kidney and other tissues, notably the surface of gills, which affects proper functioning of the organ.

A trend was obtained in the assessment of the distribution of the $\mathrm{Cd}, \mathrm{Cu}, \mathrm{Pb}, \mathrm{Zn}$ and $\mathrm{Hg}$ in the soft part of the Crustaceans ( Metapenaeus dalli, Panulirus penicillatus and Portunus petagicus) and squids (Parateuthis tunicate and Chtenopteryx sicula) collected from Jeddah Islamic port (Table 2). Trend showed the mean values of all heavy metals content in edible tissue of crustaceans and squids species higher values when compared to the edible tissue of the investigated fish species except, lead.

The pattern of accumulation of heavy metals occurrence in soft part of the crustaceans (Metapenaeus dalli and Panulirus penicillatus) and in the whole tissue of squids (Parateuthis tunicata and Chtenopteryx sicula) samples were in order of decreasing contents $\mathrm{Zn}>\mathrm{Cu}>\mathrm{Pb}>\mathrm{Cd}>\mathrm{Hg}$. Except for Portunus petagicus the pattern of accumulation of heavy metals was in order of $\mathrm{Zn}>\mathrm{Cu}>\mathrm{Cd}>\mathrm{Pb}>\mathrm{Hg}$.

Marine organisms, including fish, crustaceans and squids, may accumulate heavy metals through direct ab-

Table 2. $\mathrm{Zn}, \mathrm{Cu}, \mathrm{Cd}, \mathrm{Pb}$, and $\mathrm{Hg}$ concentrations in crustacean and squids species collected from Jeddah Islamic port, Kingdom of Saudi Arabia, Red Sea $\left(\mu \mathrm{g} \cdot \mathrm{g}^{-1}\right.$ dry weight).

\begin{tabular}{|c|c|c|c|c|c|}
\hline \multirow{2}{*}{ Species } & \multicolumn{5}{|c|}{ Heavy metals concentration $\mu \mathrm{g} \cdot \mathrm{g}^{-1}$ dry weight } \\
\hline & $\mathbf{Z n}$ & $\mathbf{C u}$ & Cd & $\mathbf{P b}$ & $\mathrm{Hg}$ \\
\hline Metapenaeus dalli & 3.758 & 0.814 & 0.067 & 0.21 & ND \\
\hline Parateuthis tunicata & 4.529 & 0.349 & 0.184 & 0.304 & ND \\
\hline Chtenopteryx sicula & 14.65 & 0.994 & 0.172 & 0.299 & ND \\
\hline Panulirus penicillatus & 11.523 & 5.97 & 0.19 & 0.466 & ND \\
\hline Portunus petagicus & 12.715 & 1.651 & 0.08 & 0.008 & ND \\
\hline Maximum & 14.65 & 5.97 & 0.19 & 0.466 & \\
\hline Minimum & 3.758 & 0.349 & 0.067 & 0.008 & \\
\hline Average & 9.435 & 1.9556 & 0.1386 & 0.2574 & \\
\hline
\end{tabular}


sorption or via their food chain and pass them to human beings, by consumption, causing chronic or acute disorder [22] [43].

The average concentration of metals in crustaceans and squids were relatively higher compared with the muscle tissues in the examined fish species. This in agreement with Kilgour (1991) [44] who indicated that animals which have close relationship with sediment, shows relatively high body concentration of metalsas well as crustaceans and squids being as a good indicators for the long-term monitoring of metal pollution in the marine environment. This can be related to several factors such as habitat, dietary uptake, pollutant bioavailability in addition to the main factor for uptake of heavy metals in Crustaceans via food which is mainly feed through sediments which consider the main reservoir of pollutions [45]. The fact that many demersal fish species are long-lived and tend to feed at higher trophic levels than their pelagic fish counterparts may lead to a potentially higher level of accumulation of persistent pollutants particularly those are not easily metabolized or degraded [46].

The amounts of heavy metals in soft tissue of crustaceans and squids were compared with those from the related species from other areas. From (Table 2) the concentrations of cadmium, copper, lead and zinc in soft tissue of shellfish in the present study were lower compared with El-Sikaily et al., (2004) [47]; He, (1996) [48] in the Egyptian Mediterranean Sea and Red Sea; Bohai Sea and Huanghai Sea, China, respectively.

High concentrations of $\mathrm{Pb}$ and $\mathrm{Zn}$ were found in crustaceans and squids samples in the present study as compared with those recorded in shellfish species studied in the Zhejiang Coast, China [49]. Furthermore, Cu and Hg were lower while Cd was agreed well when compared with those recorded in the Zhejiang Coast, China [49].

The heavy metal levels in water sample were as follows $\mathrm{Zn}>\mathrm{Cu}>\mathrm{Pb}>\mathrm{Cd}>\mathrm{Hg}$ (Figure 1). The results of metal concentrations in water were used to calculate BCFs.

The bioaccumulation factors (BAFs) of the tissues of the investigated fish species were presented in (Table 3). $\mathrm{BAF}$ is a number that describes the bioaccumulation as the ratio between the accumulated concentration of a given pollutant in any organ to the concentration in the surrounding environment according to Mackay and Fraser (2000) [14].

The results of BAFs indicated that among examined metals Zn was the most readily absorbed by fish (Table 3) and the highest BAFs for examined fish species were determined in gill of Snubnose emperor for Zn (37.269) and in the liver of Acanthopagrus bifasciatus (29.423) for $\mathrm{Cu}$.

In the edible tissue of Crustaceans and squids investigated species, the mean values of BAFs for $\mathrm{Cd}, \mathrm{Cu}$ and Zn were remarkably higher values when compared to the edible tissue of the investigated fish species, while the $\mathrm{BAFs}$ of $\mathrm{Pb}$ were also fairly low and the BAFs of $\mathrm{Hg}$ were not detected in all investigated species (Table 4).

The observed high BAF in some fish species indicates that these fishes have a high potential to concentrate heavy metals in their organs [50]. The extent of occurrence or accumulation of trace metals by organisms in different tissues is dependent on the route of entry. The accumulation process involves the biological sequestering of metals that enter the organism through respiration and epidermal. It has been indicated that BAFs from environment to fish tissue changes according to the species of the chemical, the metabolite properties of the tissues and the pollution degree of the environment [51]-[53].

The investigated species are commonly consumed seafood in many Red Sea countries. Therefore, the investi-

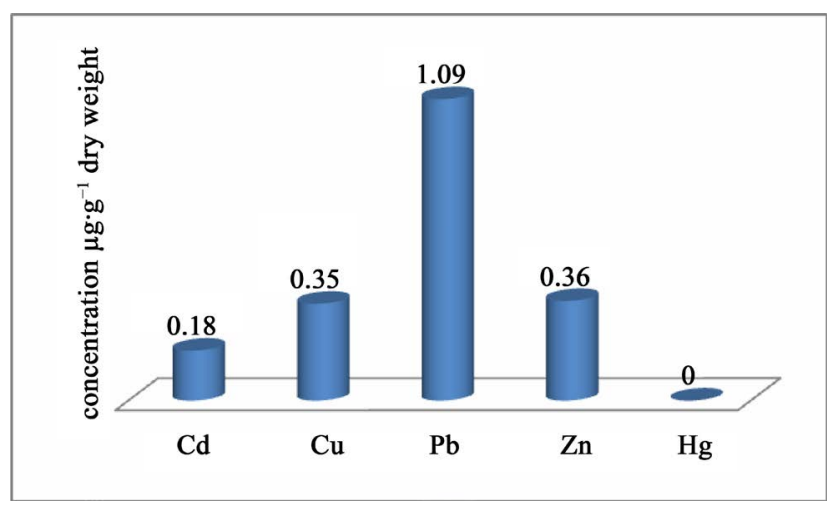

Figure 1. $\mathrm{Cd}, \mathrm{Cu}, \mathrm{Pb}, \mathrm{Zn}$ and $\mathrm{Hg}$ concentrations in sea water collected from Jeddah Islamic port, Kingdom of Saudi Arabia, Red Sea $\left(\mu \mathrm{g} \cdot \mathrm{g}^{-1}\right.$ dry weight). 





Table 4. The BAF in crustacean and squids species collected from Jeddah Islamic port, Kingdom of Saudi Arabia, Red Sea ( $\mu \mathrm{g} \cdot \mathrm{g}^{-1}$ dry weight).

\begin{tabular}{cccccc}
\hline Species & \multicolumn{5}{c}{ Heavy metals concentration ${\boldsymbol{\mu g} \cdot \mathbf{g}^{-1} \text { dry weight }}$} \\
\cline { 2 - 6 } & $\mathbf{Z n}$ & $\mathbf{C u}$ & $\mathbf{C d}$ & $\mathbf{P b}$ & $\mathbf{H g}$ \\
\hline Metapenaeus dalli & 10.439 & 2.326 & 0.372 & 0.193 & - \\
Parateuthis tunicata & 12.581 & 0.997 & 1.022 & 0.279 & - \\
Chtenopteryx sicula & 40.694 & 2.840 & 0.956 & 0.274 & - \\
Panulirus penicillatus & 32.008 & 17.057 & 1.056 & 0.428 & - \\
Portunus petagicus & 35.319 & 4.717 & 0.444 & 0.007 & - \\
Maximum & $\mathbf{4 0 . 6 9 4}$ & $\mathbf{1 7 . 0 5 7}$ & $\mathbf{1 . 0 5 6}$ & $\mathbf{0 . 4 2 8}$ & - \\
Minimum & $\mathbf{1 0 . 4 3 9}$ & $\mathbf{0 . 9 9 7}$ & $\mathbf{0 . 3 7 2}$ & $\mathbf{0 . 0 0 7}$ & - \\
Average & $\mathbf{2 6 . 2 0 8}$ & $\mathbf{5 . 5 8 7}$ & $\mathbf{0 . 7 7 0}$ & $\mathbf{0 . 2 3 6}$ & - \\
\hline
\end{tabular}

gation of heavy metal concentrations in the tissues of these species may provide useful information on the transfer of potentially toxic elements from abiotic compartments (water, sediment) to higher consumers, including man [54]. Therefore, we can conclude that, $\mathrm{Cu}$ and $\mathrm{Zn}$ concentrations of all edible tissues of the species were considerably high but lower than the permissible levels set by FAO and WHO. But the permissible limits for Cd and $\mathrm{Pb}$ were exceeded in some of the edible tissues of the analyzed species in present study.

Accumulation of $\mathrm{Cd}$ and $\mathrm{Pb}$ in edible tissues of the investigated species and other organs may be considered as an important warning signal for fish health and human consumption. The present study shows that precaution measures need to be taken in order to prevent future heavy metal pollution. Therefore, further monitoring programs should be conducted.

\section{References}

[1] UNEP/FAO (1996) Final Reports on Research Projects Dealing with Eutrophication and Heavy Metal Accumulation. UNEP. A Thesis. MAP Tech. Rep. Ser. 104, 238.

[2] Younis, A.M., Ismail, I.S., Mohamedein, L.I. and Ahmed, S.F. (2014) Spatial Variation and Environmental Risk Assessment of Heavy Metal in the Surficial Sediments along the Egyptian Red Sea Coast. CATRINA, 10, 45-52. http://dx.doi.org/10.12816/0010694

[3] Tarifeno-Silva, E., Kawasaki, L., Yn, D.P., Gordon, M.S. and Chapman, D.J. (1982) Aquacultural Approaches to Recycling Dissolved Nutrients in Secondarily Treated Domestic Waste Waters: Uptake of Dissolved Heavy Metals by Artificial Food Chains. Water Research, 16, 59-65. http://dx.doi.org/10.1016/0043-1354(82)90053-7

[4] Rayms-Keller, A., Olson, K.E., McGaw, M., Oray, C., Carlson, J.O. and Beaty, B.J. (1998) Effect of Heavy Metals on Aedes aegypti (Diptera: Culicidea) Larvae. Ecotoxicology and Environmental Safety, 39, 41-47. http://dx.doi.org/10.1006/eesa.1997.1605

[5] Zwieg, R.D., Morton, J.D. and Stewart, M.M. (1999) Source Water Quality for Aquaculture: A Guide for Assessment. The World Bank, Washington DC. http://dx.doi.org/10.1596/0-8213-4319-X

[6] Moiseenko, T.I. and Kudryavtseva, L.P. (2001) Trace Metal Accumulation and Fish Pathologies in Areas Affected by Mining and Metallurgical Enterprises in the Kola Region. Russian Environmental Pollution, 114, 285-297. http://dx.doi.org/10.1016/S0269-7491(00)00197-4

[7] Mansour, S.A. and Sidky, M.M. (2002) Ecotoxocological Studies. 3. Heavy Metals Contaminating Water and Fish from Fayoum Governorate, Egypt. Food Chemistry, 78, 15-22. http://dx.doi.org/10.1016/S0308-8146(01)00197-2

[8] Farkas, A., Salánki, J. and Specziár, A. (2003) Age and Size-Specific Patterns of Heavy Metals in the Organs of Freshwater Fish Abramis brama L. Populating a Low-Contaminated Site. Water Research, 37, 959-964. http://dx.doi.org/10.1016/S0043-1354(02)00447-5

[9] Younis, A.M. and Nafea, S.M. (2012) Impact of Environmental Conditions on the Biodiversity of Mediterranean Sea Lagoon, Burullus Protected Area, Egypt. World Applied Sciences Journal, 19, 1423-1430.

[10] El Zokm, G.M., Okbah, M.A. and Younis, A.M. (2015) Assessment of Heavy Metals Pollution Using AVS-SEM and Fractionation Techniques in Edku Lagoon Sediments, Mediterranean Sea, Egypt. Journal of Environmental Science and Health, Part A, 50, 1-14.

[11] Younis, A.M. and Nafea, E.M.A. (2015) Heavy Metals and Nutritional Composition of Some Naturally Growing Aq- 
uatic Macrophytes of Northern Egyptian Lakes. Journal of Biodiversity and Environmental Sciences (JBES), 6, 16-23.

[12] Phillips, D.J.H. and Rainbow, P.S. (1992) Biomonitoring of Trace Aquatic Contaminant. Elsevier Applied Science, London, 372.

[13] UNEP/FAO/IAEA/IOC (1984) Reference Methods for Marine Pollution Studies. UNEP, 1, 11-21.

[14] Mackay, D. and Fraser, A. (2000) Bioaccumulation of Persistent Organic Chemicals: Mechanisms and Models. Environmental Pollution, 110, 375-391. http://dx.doi.org/10.1016/S0269-7491(00)00162-7

[15] Calabrese, E.J., Canada, A.T. and Sacco, C. (1985) Trace Elements and Public Health. Annual Review of Public Health, 6, 131-146. http://dx.doi.org/10.1146/annurev.pu.06.050185.001023

[16] Hussein, A. and Khaled, A. (2014) Determination of Metals in Tuna Species and Bivalves from Alexandria, Egypt. Egyptian Journal of Aquatic Research, 40, 9-17. http://dx.doi.org/10.1016/j.ejar.2014.02.003

[17] Pourang, N., Dennis, J.H. and Ghourchian, H. (2005) Distribution of Heavy Metals in Penaeus semisulcatus from Persian Gulf and Possible Role of Metallothionein in Their Redistribution during Storage. Environmental Monitoring and Assessment, 100, 71-88. http://dx.doi.org/10.1007/s10661-005-7061-8

[18] Topcuoglu, S., Kurbasoglu, C. and Gungor, N. (2002) Heavy Metals in Organisms and Sediments from Turkish Coast of the Black Sea, 1997-1998. Environment International, 27, 521-526. http://dx.doi.org/10.1016/s0160-4120(01)00099-x

[19] Khaled, A. (2013) Assessment of Some Heavy Metals in Edible Fishes from El-Mex Bay, Alexandria, Egypt. Blue Biotechnology Journal, 2, 1-8.

[20] Keskin, Y., Baskaya, R., Ozyaral, O., Yurdun, T., Luleci, N.E. and Hayran, O. (2007) Cadmium, Lead, Mercury and Copper in Fish from the Marmara Sea, Turkey. Bulletin of Environmental Contamination and Toxicology, 78, $258-261$. http://dx.doi.org/10.1007/s00128-007-9123-9

[21] Ashraf, W. (2006) Levels of Selected Heavy Metals in Tuna Fish. Arabian Journal for Science and Engineering, 31, 89-92.

[22] Ashraf, W., Seddigi, Z., Abulkibash, A. and Khalid, M. (2006) Levels of Selected Metals in Canned Fish Consumed in Kingdom of Saudi Arabia. Environmental Monitoring and Assessment, 117, 271-279. http://dx.doi.org/10.1007/s10661-006-0989-5

[23] Al-Yousuf, M.H., El-Shahawi, M.S. and Al-Ghais, S.M. (2000) Trace Metals in Liver, Skin and Muscle of Lethrinus lentjan Fish Species in Relation to Body Length and Sex. The Science of the Total Environment, 256, 87-94. http://dx.doi.org/10.1016/S0048-9697(99)00363-0

[24] Usero, J., Izquierdo, C., Morillo, J. and Gracia, I. (2004) Heavy Metals in Fish (Solea vulgaris, Anguilla anguilla and Liza aurata) from Salt Marshes on the Southern Atlantic Coast of Spain. Environment International, 29, 949-956. http://dx.doi.org/10.1016/S0160-4120(03)00061-8

[25] FAO (1983) Compilation of Legal Limits for Hazardous Substances in Fish and Fishery Products. FAO Fisheries Circular No. 764, FAO, Rome, 102 p.

[26] Demirak, A., Yilmaz, F., Tuna, A.L. and Ozdemir, N. (2006) Heavy Metals in Water, Sediment and Tissues of Leuciscus cephalus from a Stream in Southwestern Turkey. Chemosphere, 63, 1451-1458. http://dx.doi.org/10.1016/j.chemosphere.2005.09.033

[27] Yang, R., Yao, T., Xu, B., Jiang, G. and Xin, X. (2007) Accumulation Features of Organochlorine Pesticides and Heavy Metals in Fish from High Mountain Lakes and Lhasa River in the Tibetan Plateau. Environment International, 33, 151-156. http://dx.doi.org/10.1016/j.envint.2006.08.008

[28] Jezierska, B. and Witeska, M. (2001) Metal Toxicity to Fish. Wydawnictwo Akademii Podlaskiej, Siedlce, 318 p.

[29] Hem, J.D. (1989) Study and Interpretation of the Chemical Characteristics of Natural Water. US Geological Survey, Water Supply Paper 2254.

[30] Taha, A.A. (2004) Pollution Sources and Related Environmental Impacts in the New Communities, Southeast Nile Delta, Egypt. Emirates Journal for Engineering Research, 9, 35-49.

[31] Goyer, R. (1991) Toxic Effects of Metals. In: Amdur, M.O., Doull, J.D. and Klaassen, C.D., Eds., Casarett and Doull's Toxicology, 4th Edition, Pergamon Press, New York, 623-680.

[32] Misra, P.R., Crance, K.A., Bare, R.M. and Waalkes, M.P. (1997) Lack of Correlation between the Inducibility of Metallothionein mRNA and Metallothionein Protein in Cadmium-Exposed Rodents. Toxicology, 117, 99-109. http://dx.doi.org/10.1016/S0300-483X(96)03557-3

[33] Bowen, H.J.M. (1979) Environmental Chemistry of the Elements. Academic Press, London, 269.

[34] EPA (1995) Arsenic-Freshwater Human Health Criterion for Fish Consumption. Environmental Protection Agency, Washington DC. 
[35] Tchounwou, P.B., Abdelghani, A.A., Pramar, Y.V., Heyer, L.R. and Steward, C.M. (1996) Assessment of Potential Health Risks Associated with Ingesting Heavy Metals in Fish Collected from a Hazardous-Waste Contaminated Wetland in Louisiana, USA. Reviews on Environmental Health, 11, 191-203. http://dx.doi.org/10.1515/REVEH.1996.11.4.191

[36] Chi, Q.-Q., Zhu, G.-W. and Langdon, A. (2007) Bioaccumulation of Heavy Metals in Fishes from Taihu Lake, China. Journal of Environmental Sciences, 19, 1500-1504. http://dx.doi.org/10.1016/S1001-0742(07)60244-7

[37] Dural, M., Goksu, M.Z.L. and Ozak, A.A. (2007) Investigation of Heavy Metal Levels in Economically Important Fish Species Captured from the Tuzla Lagoon. Food Chemistry, 102, 415-421. http://dx.doi.org/10.1016/j.foodchem.2006.03.001

[38] Canli, M. and Atli, G. (2003) The Relationships between Heavy Metal (Cd, Cr, Cu, Fe, Pb, Zn) Levels and the Size of Six Mediterranean Fish Species. Environmental Pollution, 121, 129-136. http://dx.doi.org/10.1016/S0269-7491(02)00194-X

[39] El-Nemr, A. (2003) Concentrations of Certain Heavy Metals in Imported Frozen Fish in Egypt. Egyptian Journal of Aquatic Biology and Fisheries, 7, 139-154.

[40] Khaled, A. (2004) Heavy Metals Concentrations in Certain Tissues of Five Commercially Important Fishes from El-Mex Bay, Alexandria, Egypt. Egyptian Journal of Aquatic Biology and Fisheries, 8, 51-64.

[41] Van Aardt, W.J. and Erdman, R. (2004) Heavy Metals (Cd, Pb, Cu, Zn) in Mudfish and Sediments from Three Hard-Water Dams of the Mooi River Catchment, South Africa. Water, 30, 211-218. http://dx.doi.org/10.4314/wsa.v30i2.5066

[42] Mwashot, B.M. (2003) Levels of Cadmium and Lead in Water, Sediments Selected Fish Species in Mombasa, Kenya. Western Indian Ocean Journal of Marine Science, 2, 25-34.

[43] Waalkes, M.P. (2000) Cadmium Carcinogenesis in Review. Journal of Inorganic Biochemistry, 79, $241-244$. http://dx.doi.org/10.1016/s0162-0134(00)00009-x

[44] Kilgour, B.W. (1991) Cadmium Uptake from Cadmium-Spiked Sediments by Four Fresh Water Invertebrates. Bulletin of Environmental Contamination and Toxicology, 47, 70-75. http://dx.doi.org/10.1007/BF01689455

[45] Younis, A.M., El-Zokm, G.M. and Okbah, M.A. (2014) Spatial Variation of Acid-Volatile Sulfide and Simultaneously Extracted Metals in Egyptian Mediterranean Sea Lagoon Sediments. Environmental Monitoring and Assessment, 186, 3567-3579. http://dx.doi.org/10.1007/s10661-014-3639-3

[46] Said, T.O., Farag, R.S., Younis, A.M. and Shreadah, M.A. (2006) Organotin Species in Fish and Bivalves Samples Collected from the Egyptian Mediterranean Coast of Alexandria, Egypt. Bulletin of Environmental Contamination and Toxicology, 77, 451-458. http://dx.doi.org/10.1007/s00128-006-1086-8

[47] El-Sikaily, A., Khaled, A. and El Nemr, A. (2004) Heavy Metals Monitoring Using Bivalves from Mediterranean Sea and Red Sea. Environmental Monitoring and Assessment, 98, 41-58. http://dx.doi.org/10.1023/B:EMAS.0000038178.98985.5d

[48] He, G.K. (1996) Levels of Heavy Metals in Molluscs from the Coastal Region of Bohaisea and Huanghai Sea. China Environmental Science, 16, 96-100.

[49] Huang, H., Wu, J.Y. and Wu, J.H. (2007) Heavy Metal Monitoring Using Bivalved Shellfish from Zhejiang Coastal Waters, East China Sea. Environmental Monitoring and Assessment, 129, 315-320. http://dx.doi.org/10.1007/s10661-006-9364-9

[50] Eja, M.E., Ogri, O.R. and Arikpo, G.E. (2003) Bioconcentration of Heavy Metals in Surface Sediments from the Great Kwa Rivers Estuary, Calabar, South Eastern Nigeria. Journal of Nigerian Environmental Society, 2, 247-256.

[51] Ayas, Z. (2007) Trace Element Residues in Eggshells of Grey Heron (Ardea cinerea) and Black-Crowned Night Heron (Nycticorax nycticorax) from Nallihan Bird Paradise, Ankara-Turkey. Ecotoxicology, 16, 347-352. http://dx.doi.org/10.1007/s10646-007-0132-6

[52] Ayas, Z., Ekmekci, G., Ozmen, M. and Yerli, S.V. (2007) Histopathological Changes in the Livers and Kidneys of Fish in Sariyar Reservoir, Turkey. Environmental Toxicology and Pharmacology, 23, 242-249. http://dx.doi.org/10.1016/j.etap.2006.11.003

[53] Ozmen, M., Ayas, Z., Güngördü, A., Ekmekci, G.F. and Yerli, S. (2008) Ecotoxicological Assessment of Water Pollution in Sariyar Dam Lake, Turkey. Ecotoxicology and Environmental Safety, 70, 163-173. http://dx.doi.org/10.1016/j.ecoenv.2007.05.011

[54] Campanella, L., Conti, M.E., Cubadda, F. and Sucapane, C. (2001) Trace Metals in Seagrass and Mollusks from an Uncontaminated Area in the Mediterranean. Environmental Pollution, 111, 117-126. http://dx.doi.org/10.1016/S0269-7491(99)00327-9 